\begin{tabular}{|l|l|l||}
\hline \multicolumn{2}{|c|}{ PublisherInfo } \\
\hline \hline PublisherName & $:$ & BioMed Central \\
\hline \hline PublisherLocation & $:$ & London \\
\hline \hline PublisherImprintName & $:$ & BioMed Central \\
\hline \hline
\end{tabular}

\title{
Placental profiling
}

\begin{tabular}{|l|l|l||}
\hline \multicolumn{2}{|c|}{ ArticleInfo } \\
\hline \hline ArticleID & $:$ & 4247 \\
\hline \hline ArticleDOI & $:$ & $10.1186 /$ gb-spotlight-20011108-01 \\
\hline \hline ArticleCitationID & $:$ & spotlight-20011108-01 \\
\hline \hline ArticleSequenceNumber & $:$ & 318 \\
\hline \hline ArticleCategory & $:$ & Research news \\
\hline ArticleFirstPage & $:$ & 1 \\
\hline \hline ArticleLastPage & $:$ & 2 \\
\hline \hline & $:$ & RegistrationDate : 2001-11-08 \\
ArticleHistory & $:$ & OnlineDate \\
\hline \hline ArticleCopyright & $:$ & BioMed Central Ltd2001-11-08 \\
\hline \hline ArticleGrants & $:$ & \\
\hline \hline ArticleContext & $:$ & 130592211 \\
\hline \hline
\end{tabular}




\section{Jonathan B Weitzman}

Email: jonathanweitzman@hotmail.com

The extraembryonic lineage is the first to differentiate in mammals following fertilization. In the November 6 Proceedings of the National Academy of Sciences, Hemberger et al. report the use of cDNA subtraction and microarray hybridisation to screen for genes implicated in placentogenesis (Proc Natl Acad Sci USA 2001, 98:13126-13131). They isolated the ectoplacental cone region of mouse conceptuses at embryonic day 7.5 (E7.5) and mature E17.5 placentas, and performed subtractive hybridization to generate two pools of cDNA, enriched for genes specific for E7.5 or 17.5. They then used these cDNA probes to screen microarrays containing 25,000 I.M.A.G.E. cDNA clones, and identified 488 clones with the E7.5-specific probe and 150 with the E17.5-specific probe. Over half of these correspond to genes not previously associated with placental development. Differential expression of several of the genes was confirmed by in situhybridization analysis. In addition to identifying a large number of genes differentially expressed in extraembryonic tissues, this study shows the power of combining cDNA subtraction and microarray hybridization techniques.

\section{References}

1. Implantation and the placenta: key pieces of the development puzzle.

2. Proceedings of the National Academy of Sciences, [http://www.pnas.org] 